\title{
The relationship between RSUME and VHL/HIF-1 $\alpha$ signalling pathway in renal cell carcinoma
}

Yuanliang Wang, Xin Wang, Faliang Zhao, Anjian Chen, Tiangcai Liang, Yang Du, Hao Li, Jiang Du, Zifeng Fu, Guobiao Liang

Departments of Urology, The Affiliated Hospital of Zunyi Medical University, Zunyi, Guizhou, China

Submitted: 17 March 2020

Accepted: 16 July 2020

Arch Med Sci

DOI: https://doi.org/10.5114/aoms.2020.98040

Copyright (c) 2020 Termedia \& Banach

\section{Abstract}

Introduction: Renal cell carcinoma (RCC) is characterised by loss of the von Hippel-Lindau tumour suppressor gene $(V H L)$, and the functional tumourigenic consequences of this loss have been used to develop therapies for advanced renal cell carcinoma, such as targeting activation of the HIF pathway. Human RWD containing sumoylation enhancer (RSUME) has been previously reported to play a promoting role in pituitary tumours. However, the exact role of RSUME in RCC remains unclear. The present study aimed to investigate the expression levels of VHL, HIF-1 $\alpha$, and RSUME genes and proteins in human RCC tissues, and their correlations.

Material and methods: Immunohistochemistry and real-time PCR were applied to detect the expression levels of VHL, HIF-1 $\alpha$, and RSUME in normal renal tissue (control group) and RCC (experimental group).

Results: The results revealed that RSUME and HIF-1 $\alpha$ were significantly upregulated in RCC tissues compared with normal renal tissues $(p<0.05)$, while the expression level of $V H L$ was significantly lower than that in normal renal tissues $(p<0.05)$. Correlation analysis results showed that the expression of VHL was negatively correlated with HIF-1 $\alpha$ and RSUME, respectively $(p<0.05)$. However, a positive correlation between RSUME and HIF-1 $\alpha$ expression was observed $(p<0.05)$.

Conclusions: These results suggested that upregulated expression of RSUME may be involved in the formation and progression of renal cell carcinoma via interaction with VHL/HIF-1 $\alpha$ signalling pathway, and thus RSUME may be a novel potential therapeutic target for renal cell carcinoma.

Key words: renal cell carcinoma, VHL, HIF-1 1 , human RWD-containing sumoylation enhancer.

\section{Introduction}

Renal cell carcinoma (RCC) is the most common kidney cancer type, with an incidence rate of $2-3 \%$ among all adult malignancies. The incidence of RCC involves multiple genes, among which VHL (von Hippel-Lindau) is the most closely related to RCC [1]. VHL gene is a tumour suppressor gene, mutation of which will lead to $V H L$ gene function inactivation [2], and inactivation of $V H L$ gene prevents hypoxia-induced factor (HIF) from being effectively degraded, resulting in vascular endothelial growth factor (VEGF), transforming growth factor- $\alpha$ (TGF- $\alpha$ ), and epithelial growth factor receptor (EGFR) activation $[3,4]$. These factors contribute to tumour growth. In recent years, great progress has been made in the

\author{
Corresponding author: \\ Dr Guobiao Liang \\ Department of Urology \\ Affiliated Hospital \\ of Zunyi Medical \\ University \\ 149 Dalian Road \\ Zunyi, Guizhou 563000 \\ China \\ Phone: +86 18786916696 \\ Fax: +86 21-64085875 \\ E-mail: lgb1111@126.com
}


study of the VHL gene, which has not only promoted understanding of the pathogenesis of renal cell carcinoma, but also has had a profound impact on its diagnosis and treatment. However, the current overall effect of renal cancer is still unsatisfactory, and there are still many side effects and drug-resistance problems of molecularly targeted drugs targeting the VHL/HIF signalling pathway. Therefore, an in-depth understanding of the pathogenesis of renal cell carcinoma and the discovery of new therapeutic targets are necessary $[5,6]$.

Human RWD-containing sumoylation enhancer (RSUME) protein is expressed in multiple human tissues [7]. Hypoxia, $\mathrm{CoCl} 2$, and heat shock can cause RSUME up-regulated expression. Shan et al. [8] found that the main function of RSUME in pituitary tumours is to stabilise the transcription and expression activity of HIF- $1 \alpha$ through the regulation of small ubiquitin-related modifiers (SUMO), promoting the invasion of pituitary tumours. Chen et al. [9] demonstrated that RSUME is significantly upregulated in glioblastoma, and that it serves an oncogenic role in the regulation of the malignant phenotypes of glioblastoma cells via mediation of the activity of PI3K/AKT signalling. However, the exact role of RSUME in RCC and its relationship with VHL/HIF signalling pathway remains unclear [10].

The aim of this study was to examine the expression of VHL, HIF- $1 \alpha$, and RSUME genes and proteins in normal renal tissues (control group) and RCC (experimental group), and to analyse their expression differences and relationships, providing a basis for further research on the pathogenesis of RCC.

\section{Material and methods}

\section{Experimental materials}

\section{Experimental specimens}

Specimens were obtained between November 2013 and October 2015 from the Department of Urology at the Affiliated Hospital of Zunyi Medical University. The normal renal tissue (control group) included traumatic renal rupture nephrectomised kidney tissue $(n=3)$ and normal renal tissue surrounding renal angiomyolipoma $(n=7)$. The experimental group consisted of RCC tissues $(n=10)$ (all specimens were collected after the patients' informed consent was obtained). No cases underwent radiation or chemotherapy before surgery. Totally there were 14 males and 6 females, aged 32-67 years (mean: $46.25 \pm 8.48$ years). The tumour diameters were between 1.5 and $7.0 \mathrm{~cm}$ (mean: $4.66 \pm 1.86 \mathrm{~cm}$ ) (Table I).

\section{Primers}

According to the VHL genome sequence in GenBank, human $\beta$-actin primers, human $V H L$ prim- ers, human HIF-1 $\alpha$ primers, and human RSUME primers were synthesised by Shanghai Jierui Bioengineering Co., Ltd. (Table II).

\section{Experimental methods}

Haematoxylin and eosin (HE) staining was used to observe the pathological changes of renal tissue.

Paraffin-embedded sections of $5 \mu \mathrm{m}$ thickness were prepared and dewaxed, dehydrated, and then visualised under a microscope.

Immunohistochemistry was used to detect the expression of VHL, HIF-1 $\alpha$, and RSUME proteins in each group.

Paraffin-embedded sections of $5 \mu \mathrm{m}$ thickness were prepared and dewaxed: dehydrated for 5 min, then phosphate-buffered saline (PBS) was used to wash. Endogenous peroxidase activity was blocked by incubating the sections in $0.5 \%$ hydrogen peroxide for $10 \mathrm{~min}$ at room temperature. They were then immersed in a $10 \mathrm{mM}$ citrate buffer (pH 6.0) and incubated in a microwave oven at $100^{\circ} \mathrm{C}$ for $15 \mathrm{~min}$. After that they were cooled to room temperature. Following blocking with $5 \%$ foetal bovine serum, the sections were incubated with primary antibodies at $4^{\circ} \mathrm{C}$ overnight. The following primary antibodies were used: $\mathrm{VHL}$ rabbit anti-human primary antibody (Beijing Boaosen Biotechnology Co., Ltd., BS-1367R, 1 : 100 dilution), $\mathrm{HIF}-1 \alpha$ rabbit anti-human primary antibody (Beijing Boaosen Biotechnology Co., Ltd., BS-0737R, 1 : 100 dilution), and RSUME rabbit anti-human primary antibody (Proteintech, USA, 22737-1-AP, 1 : 50 dilution). Sections were washed with PBS and then incubated with secondary antibody for $45 \mathrm{~min}$ at room temperature. The following secondary antibodies were used: Goat anti-rabbit IgG $(\mathrm{H}+\mathrm{L}$ ) and HRP (Beijing MDL Corporation, MD2141). The immunoreactivity was visualised using a DAB kit (Beijing Boaosen Biotechnology Co., Ltd., BS-1367R, 1 : 100 dilution). The sections were counterstained with haematoxylin. For the negative controls, the primary antibody was replaced with PBS. The images were acquired using a Leica Qwin image processing system (Leica, Germany). Six fields of view were randomly taken from each slice in a 400-fold field of view. Image-proplus 6.0 image analysis software (US) was used to measure the integrated optical density (IOD) of each image.

Real time-PCR was used to detect the expression of VHL, HIF- $1 \alpha$, and RSUME mRNA in normal renal tissue (control group) and sporadic renal cell carcinoma tissues (experimental group).

Total RNA was extracted using TriQuick Reagent kits (Beijing Suo Laibao Technology Co., Ltd., R1100). Then, RNA was reversely transcribed into cDNA using PrimeScriptTM RT Kit (Dalian TAKARA Co., Ltd., RR037A). Real-time qPCR was performed 
Table I. Characteristics of patients

A. Control group

\begin{tabular}{|lccccc|}
\hline $\begin{array}{l}\text { Patient } \\
\text { number }\end{array}$ & Gender & Age & Diagnosis & $\begin{array}{c}\text { Tumour } \\
\text { diameter } \\
{[\mathrm{cm}]}\end{array}$ & Surgical method \\
\hline Case 1 & Female & 32 & Traumatic renal rupture (right) & - & Nephrectomy \\
\hline Case 2 & Male & 42 & Traumatic renal rupture (left) & - & Nephrectomy \\
\hline Case 3 & Female & 55 & Traumatic renal rupture (left) & - & Nephrectomy \\
\hline Case 4 & Male & 60 & Renal angiomyolipoma (left) & 5 & $\begin{array}{c}\text { Nephron-sparing } \\
\text { surgery }\end{array}$ \\
\hline Case 5 & Male & 44 & Renal angiomyolipoma (left) & 3.9 & $\begin{array}{c}\text { Nephron-sparing } \\
\text { surgery }\end{array}$ \\
\hline Case 6 & Male & 40 & Renal angiomyolipoma (right) & 3.8 & $\begin{array}{c}\text { Nephron-sparing } \\
\text { surgery }\end{array}$ \\
\hline Case 7 & Male & 44 & Renal angiomyolipoma (right) & 3.1 & $\begin{array}{c}\text { Nephron-sparing } \\
\text { surgery }\end{array}$ \\
\hline Case 8 & Male & 42 & Renal angiomyolipoma (right) & 1.9 & $\begin{array}{c}\text { Nephron-sparing } \\
\text { surgery }\end{array}$ \\
\hline Case 9 & Female & 67 & Renal angiomyolipoma (left) & 4.6 & $\begin{array}{c}\text { Nephron-sparing } \\
\text { surgery }\end{array}$ \\
\hline Case 10 & Female & 39 & Renal angiomyolipoma (right) & 1.5 & $\begin{array}{c}\text { Nephron-sparing } \\
\text { surgery }\end{array}$ \\
\hline
\end{tabular}

B. Experimental group

\begin{tabular}{|c|c|c|c|c|c|c|}
\hline $\begin{array}{l}\text { Patient } \\
\text { number }\end{array}$ & Gender & Age & Diagnosis & $\begin{array}{c}\text { Tumour } \\
\text { diameter } \\
{[\mathrm{cm}]}\end{array}$ & $\begin{array}{l}\text { Tumour } \\
\text { stage }\end{array}$ & Surgical method \\
\hline Case 1 & Female & 42 & $\begin{array}{l}\text { Renal clear cell } \\
\text { carcinoma (left) }\end{array}$ & 6.6 & $\mathrm{~T} 1 \mathrm{~b}$ & Radical nephrectomy \\
\hline Case 2 & Male & 62 & $\begin{array}{l}\text { Renal clear cell } \\
\text { carcinoma (right) }\end{array}$ & 5.7 & $\mathrm{~T} 1 \mathrm{~b}$ & Radical nephrectomy \\
\hline Case 3 & Male & 48 & $\begin{array}{c}\text { Renal clear cell } \\
\text { carcinoma (right) }\end{array}$ & 2.9 & T1a & Radical nephrectomy \\
\hline Case 4 & Female & 45 & $\begin{array}{c}\text { Renal clear cell } \\
\text { carcinoma (right) }\end{array}$ & 6.4 & $\mathrm{~T} 1 \mathrm{~b}$ & Radical nephrectomy \\
\hline Case 5 & Male & 40 & $\begin{array}{l}\text { Renal clear cell } \\
\text { carcinoma (left) }\end{array}$ & 6.9 & $\mathrm{~T} 1 \mathrm{~b}$ & Radical nephrectomy \\
\hline Case 6 & Male & 46 & $\begin{array}{l}\text { Renal clear cell } \\
\text { carcinoma (right) }\end{array}$ & 7 & $\mathrm{~T} 1 \mathrm{~b}$ & Radical nephrectomy \\
\hline Case 7 & Male & 44 & $\begin{array}{l}\text { Renal clear cell } \\
\text { carcinoma (left) }\end{array}$ & 3.2 & T1a & Radical nephrectomy \\
\hline Case 8 & Male & 45 & $\begin{array}{l}\text { Renal clear cell } \\
\text { carcinoma (left) }\end{array}$ & 6.5 & $\mathrm{~T} 1 \mathrm{~b}$ & Radical nephrectomy \\
\hline Case 9 & Male & 43 & $\begin{array}{l}\text { Renal clear cell } \\
\text { carcinoma (right) }\end{array}$ & 3.4 & T1a & Radical nephrectomy \\
\hline Case 10 & Male & 45 & $\begin{array}{l}\text { Renal clear cell } \\
\text { carcinoma (right) }\end{array}$ & 6.9 & $\mathrm{~T} 1 \mathrm{~b}$ & Radical nephrectomy \\
\hline
\end{tabular}

Table II. Primer sequences

\begin{tabular}{|lccc|}
\hline Gene & GenBank Acc. & Forward primer (5'-3') & Reverse primer (5'-3') \\
\hline$\beta$-actin & NC_000007.14 & GACAGGATGCAGAAGGAGATTACT & TGATCCACATCTGCTGGAAGGT \\
\hline VHL & NC_000003.12 & CACACGATGGGCTTCTGGTTA & TCAGGCTTGACTAGGCTCCG \\
\hline HIF-1 $\alpha$ & NC_000014.9 & GACAAGCCACCTGAGGAGAG & CACACGCGGAGAAGAGAAGG \\
\hline RSUME & NC_000001.11 & GATTTATGGATGCGGATATACCT & CAACGCTGAATACTCTTTGACTT \\
\hline
\end{tabular}


on a CFX96 Touch fluorescence quantitative PCR amplification instrument in triplicate for each protocol using the SYBR ${ }^{\circledR}$ Premix Ex TaqTM II (Dalian TAKARA Co. LTD, RR820A; Dalian, China).

\section{Ethical approval}

The present study was approved by the Ethics Committee of Affiliated Hospital of Zunyi Medical University.

\section{Statistical analysis}

Statistical analysis was performed using SPSS 17.0; data are represented as mean \pm SD. Independent samples $T$ test was used for comparison between the normal kidney tissue group and the renal cell carcinoma (RCC) groups. The association between VHL, HIF-1 $\alpha$, and RSUME was evaluated using the Spearman's correlation test. The chisquare $\left(\chi^{2}\right)$ test was applied to examine the correlation between RSUME expression and clinical parameters. $P<0.05$ was considered to indicate a statistically significant difference.

\section{Results}

\section{Histopathological changes (HE staining)}

\section{Normal kidney tissue}

The glomeruli and tubular structures were normal under the microscope (Figure $1 \mathrm{~A})$.

\section{Renal cell carcinoma (RCC)}

Glomerular and tubular structural damage was observed under the microscope, the tumour cells were larger, round, or polygonal, the cytoplasm was transparent, the nucleus was located in centre, and the cells were arranged in pieces (Figure $1 \mathrm{~B}$ ).
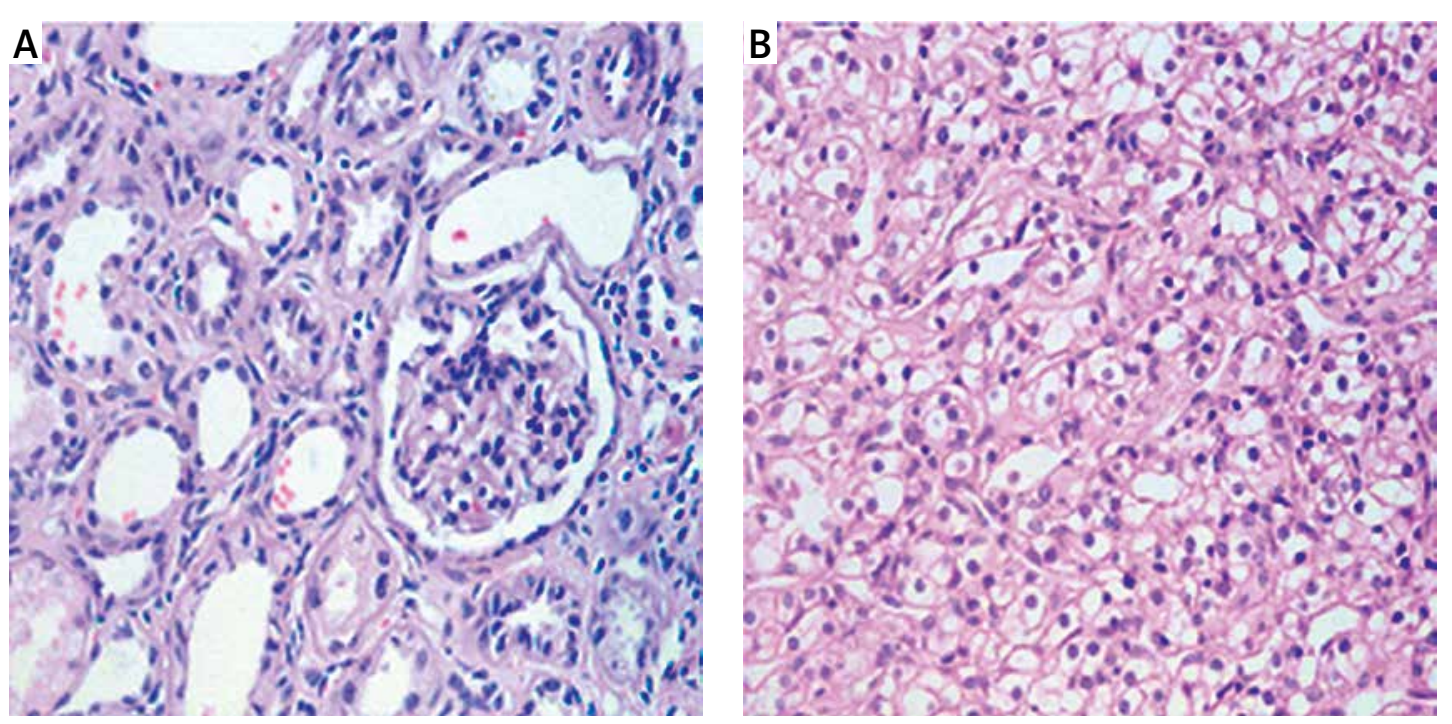

Figure 1. Histopathological changes in each group (HE, 400x): A - normal kidney tissue, B - renal cell carcinoma (RCC)

\section{Immunohistochemistry (IHC)}

The VHL and RSUME proteins were mainly expressed in the cytoplasm of glomeruli, renal tubules, and tumour cells. No expression was found in the nucleus. HIF-1 $\alpha$ protein was mainly expressed in glomeruli, renal tubules, tumour cells, cytoplasm, and some cell nuclei. There was no expression in both nucleus and nucleoli (Figures 2 A-D).

Results showed that the expression level of $\mathrm{VHL}$ in RCC was significantly lower than that in normal kidney tissue $(p<0.05)$, and the expression levels of HIF- $1 \alpha$ and RSUME protein were significantly higher than those in normal kidney tissue ( $p<$ 0.05) (shown in Table III and Figures 2 E).

Spearman correlation analysis of immunohistochemical data showed that VHL was negatively correlated with the expression of HIF- $1 \alpha$ and RSUME protein expression $(r=-0.6905, p<0.05$; $r=-0.7281, p<0.05)$, but RSUME was positively correlated with HIF-1 $\alpha$ protein expression $(r=$ $0.8526, p<0.05$ ) (Figure $2 \mathrm{~F}$ ).

\section{Real time-PCR}

RT-PCR standard curve was shown in (Figure $3 \mathrm{~A}$ ). The amplification curves of VHL, HIF-1 $\alpha$, and RSUME mRNAs as well as $\beta$-actin were an S-type smooth curve. The dissolution curve showed a single-peak (Figures 3 B-E).

\section{Expression changes of VHL, HIF-1 $\alpha$, and RSUME mRNAs}

The expression level of VHL mRNA in RCC tissues was significantly lower than that in normal renal tissues $(p<0.05)$, while the expression levels of HIF-1 $\alpha$ and RSUME mRNA in RCC tissues were significantly higher than those in normal renal tissues $(p<0.05)$ (Table IV and Figure 3 F). .

.




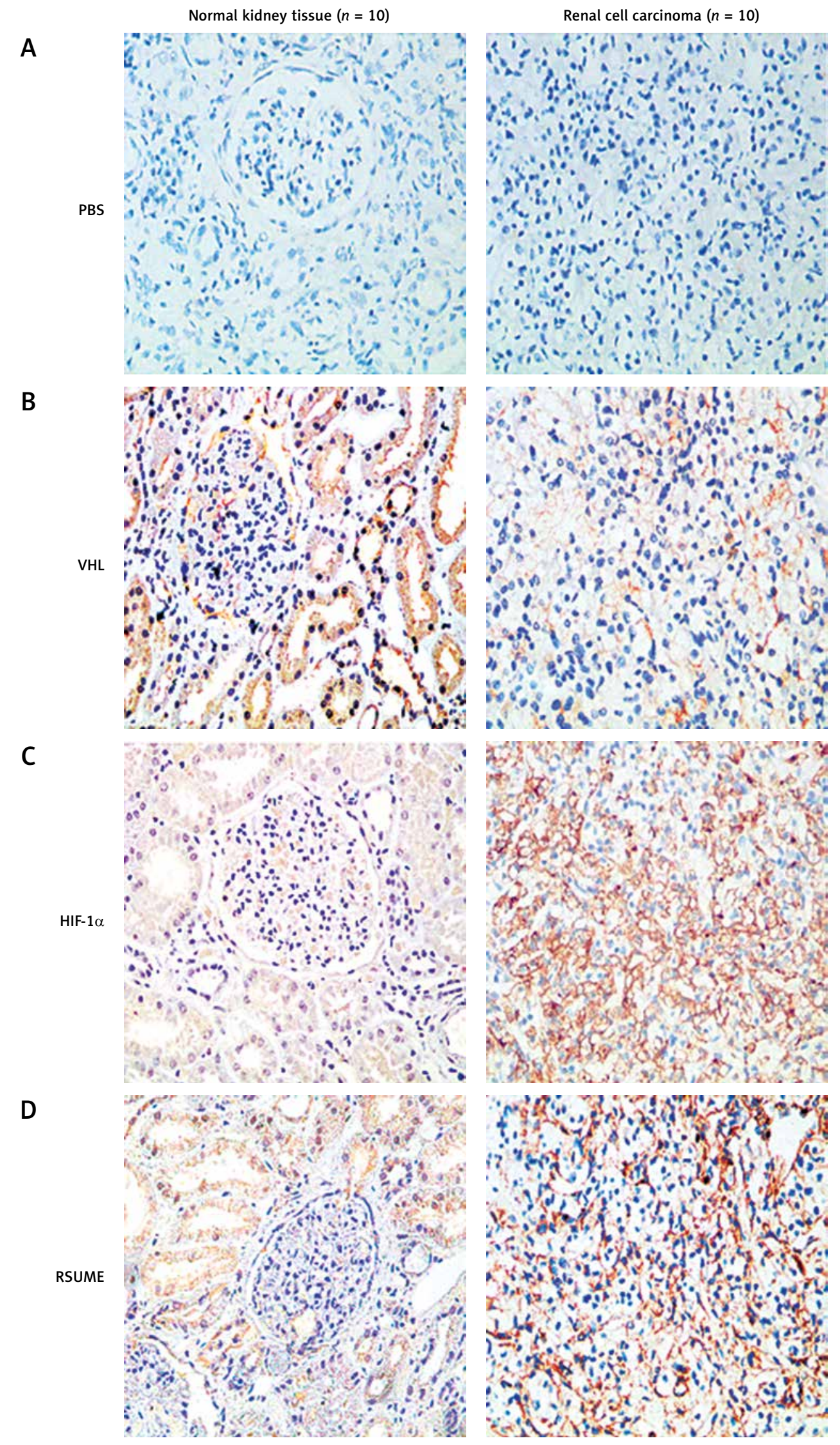

Figure 2. Immunohistochemical staining of VHL, HIF-1 $\alpha$, RSUME in each group. A - Negative control in each group (400x). B - Expression of VHL in each group (400x). C - Expression of HIF-1 $\alpha$ in each group (400x). D - Expression of RSUME in each group (400x) 


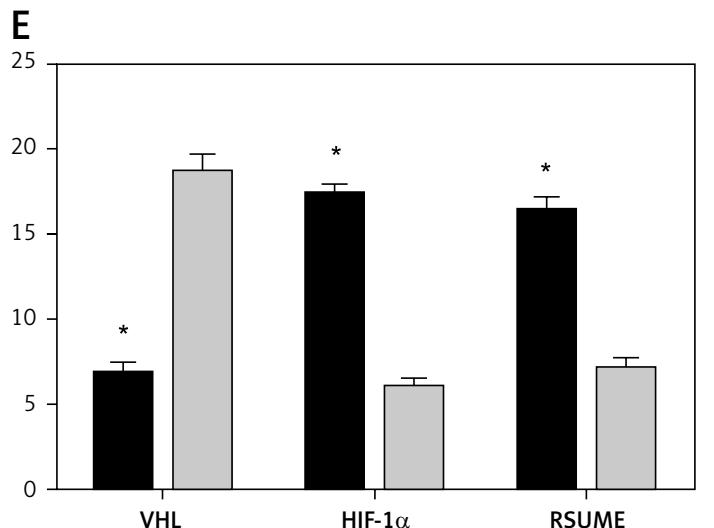

Renal cell carcinoma $(n=10) \quad \square$ Normal renal tissue $(n=10)$

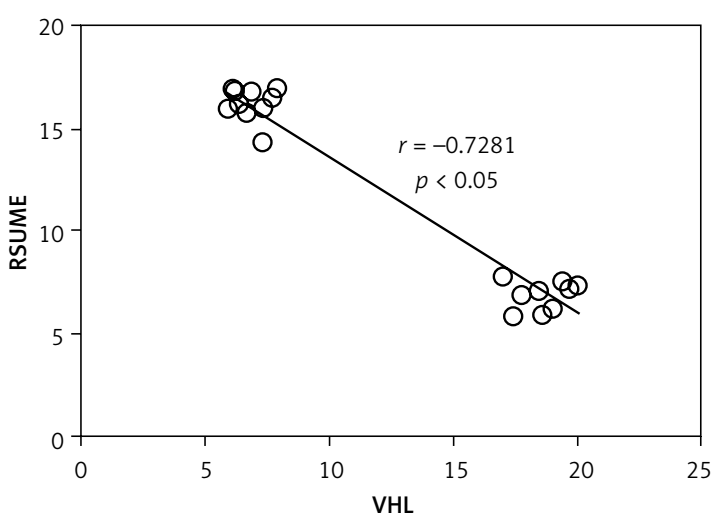

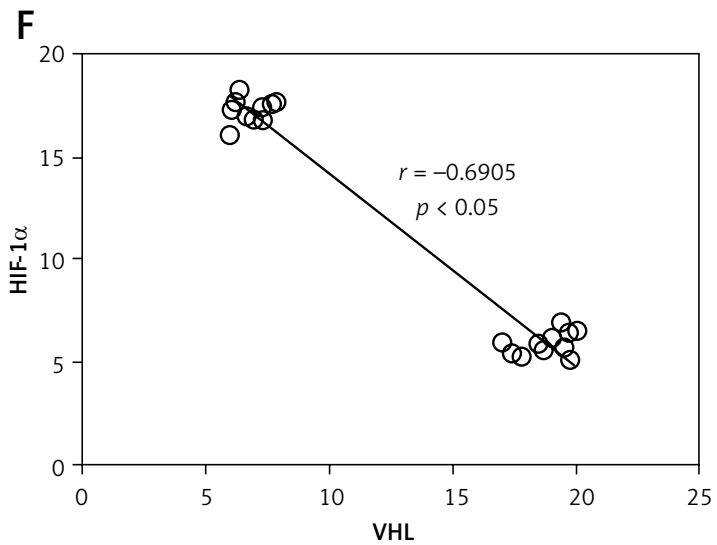

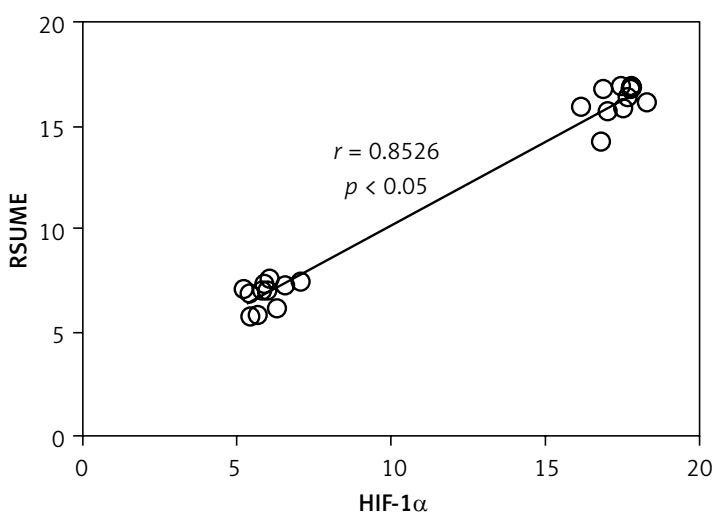

Figure 2. Cont. E - IOD values of VHL, HIF-1 $\alpha$, and RSUME. F - Correlation of VHL, HIF-1 $\alpha$, and RSUME proteins

Table III. Relative expression levels of VHL, HIF-1 $\alpha$, and RSUME proteins in each group (IOD, mean \pm SD)

\begin{tabular}{|lccc|}
\hline Group & VHL & HIF-1 $\alpha$ & RSUME \\
\hline Normal renal tissue $(n=10)$ & $18.62 \pm 1.02$ & $5.92 \pm 0.57$ & $7.00 \pm 0.67$ \\
\hline Renal cell carcinoma $(n=10)$ & $6.75 \pm 0.68^{*}$ & $17.30 \pm 0.61^{*}$ & $16.26 \pm 0.81^{*}$ \\
\hline
\end{tabular}

${ }^{\star} P<0.05$ compared with normal kidney tissue.

\section{Correlation analysis of VHL, HIF-1 $\alpha$,} and RSUME mRNAs

VHL was negatively correlated with the expression of HIF-1 $\alpha(r=-0.7772, p<0.05)$ and VHL was negatively correlated with the expression of RSUME ( $r=-0.7694, p<0.05)$, but RSUME was positively correlated with the expression of HIF- $1 \alpha$ $(r=0.9983, p<0.05)$ (Figure $3 \mathrm{G})$.

The correlation between VHL, HIF-1, and RSUME expression and clinical parameters

In order to compare the expression of VHL, HIF$1 \alpha$, and RSUME with clinicopathological parameter, samples were grouped as VHL (high), HIF-1 $\alpha$, and RSUME (low) and as VHL (low), HIF-1 $\alpha$, and RSUME (high). The $\chi^{2}$ test revealed no significant correlation between VHL, HIF-1, and RSUME expression and age $(p=0.606)$, gender $(p=0.329)$, and tumour diameter $(p=0.092)$ (Table V).

\section{Discussion}

Renal cell carcinoma (RCC) affects nearly 300,000 people worldwide annually and is responsible for nearly 100,000 deaths each year. RCC has been found to have lost the von Hippel-Lindau tumour suppressor gene (VHL) function by mutation, deletion, or methylation in up to $90 \%$ of tumours [11, 12].

Oxidative stress contributes to all three phases of carcinogenesis and represents a concomitant condition in RCC [4]. HIF is a key factor in the regulation of tumour neovascularisation. In cases of tissue hypoxia excessive accumulation of HIF upregulates angiogenic genes to improve that condition. It was observed that when the $V H L$ gene mutated, $V H L$ protein cannot be encoded or was functionally inactivated, resulting in reduced HIF degradation and abnormal accumulation under normal oxygen partial pressure, which in turn promoted increased transcription 
A

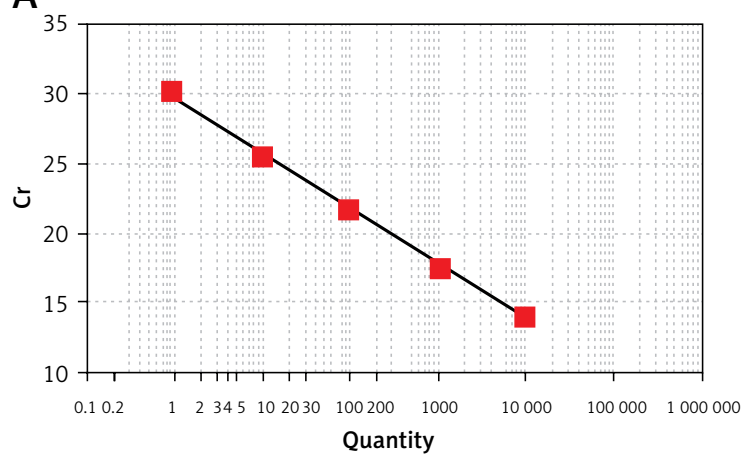

B

Amplification plot
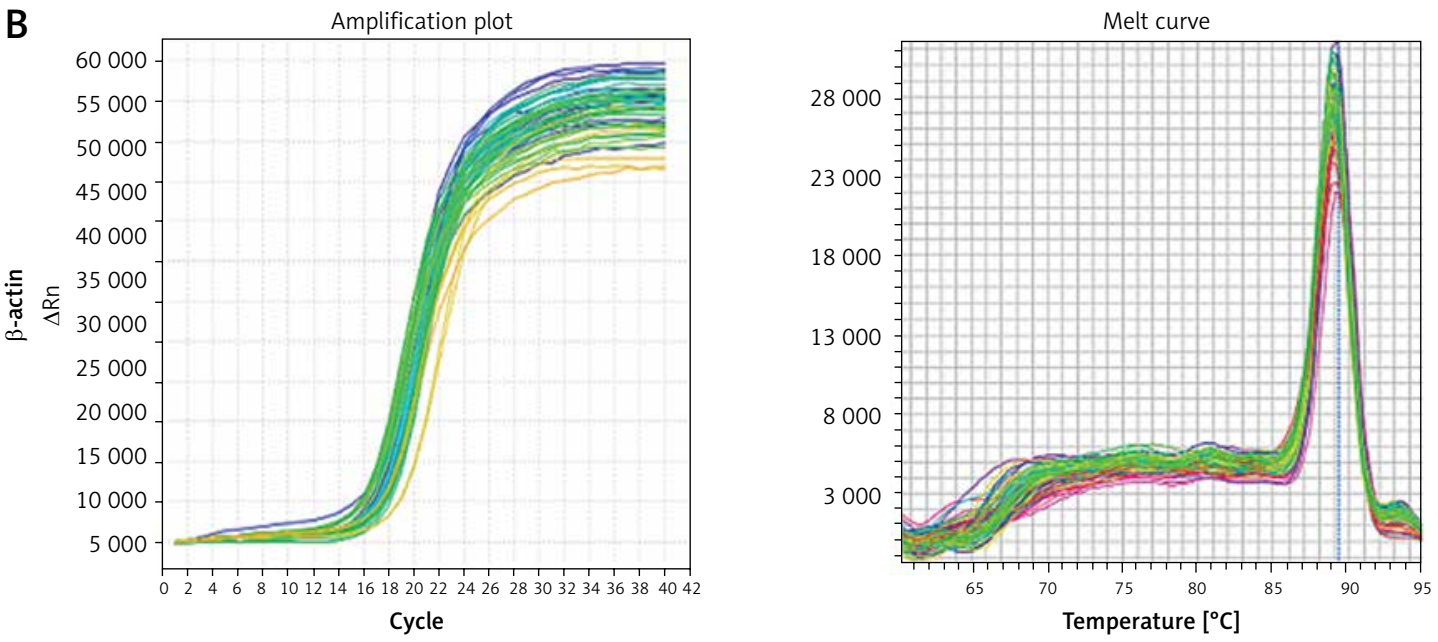

C

Amplification plot
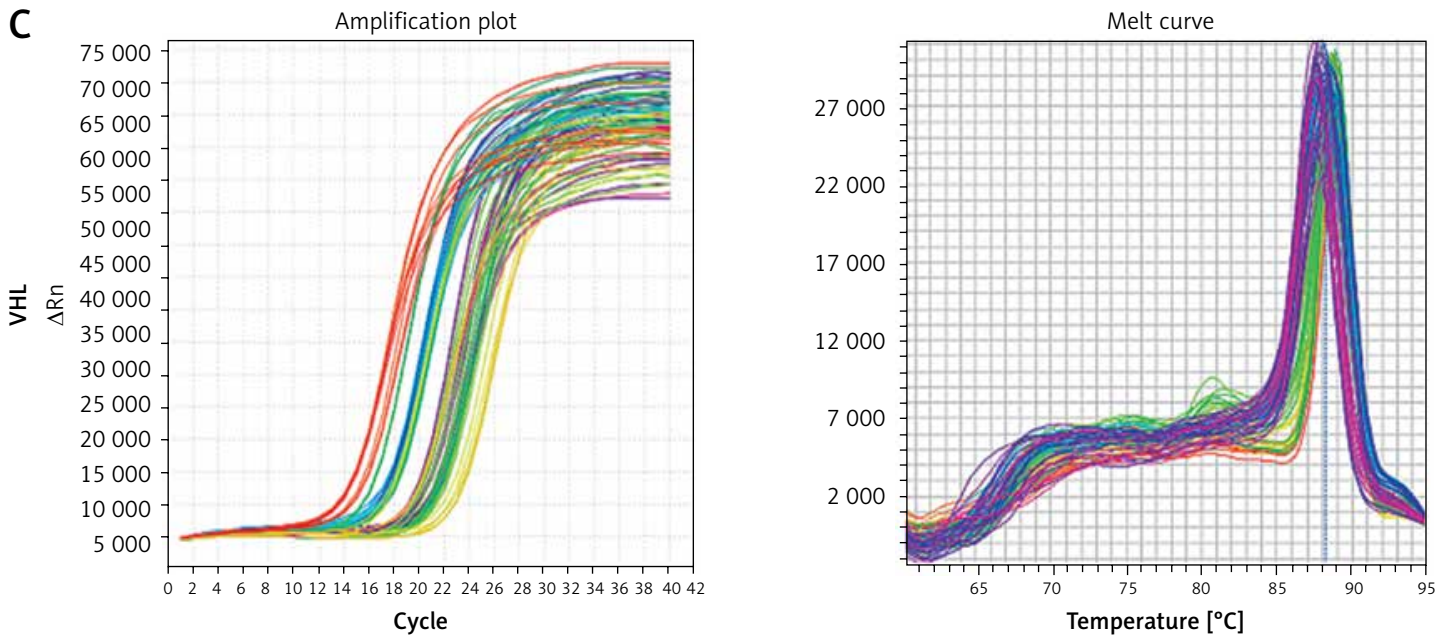

Figure 3. A - RT-PCR $\beta$-actin standard curve. B - $\beta$-actin amplification curve and dissolution curve. $\mathbf{C}-\mathrm{VHL}$ amplification curve and dissolution curve

of multiple cytokines, such as VEGF, glucose transporter-1 (GLUT-1), platelet-derived growth factor-b (PDGF-b), and TGF- $\alpha[13]$. These cytokines are involved in physiological processes such as blood vessel growth, cell energy metabolism, apoptosis, and cell cycle, and have a close relationship with the development of tumours [14].

Although molecularly targeted drugs targeting the VHL/HIF signalling pathway showed a good curative effect on RCC, there are still many prob- lems, such as side effects and drug resistance, to be solved, so new therapeutic targets are urgently needed [5].

RSUME is a gene that promotes protein sumoylation [15]. Contrary to ubiquitination, SUMO does not lead to protein degradation but protects the protein from degradation by ubiquitination and affects the protein-protein interaction through post-translational modification [16, 17]. RSUME expression can be detected in various tissues such as 
D

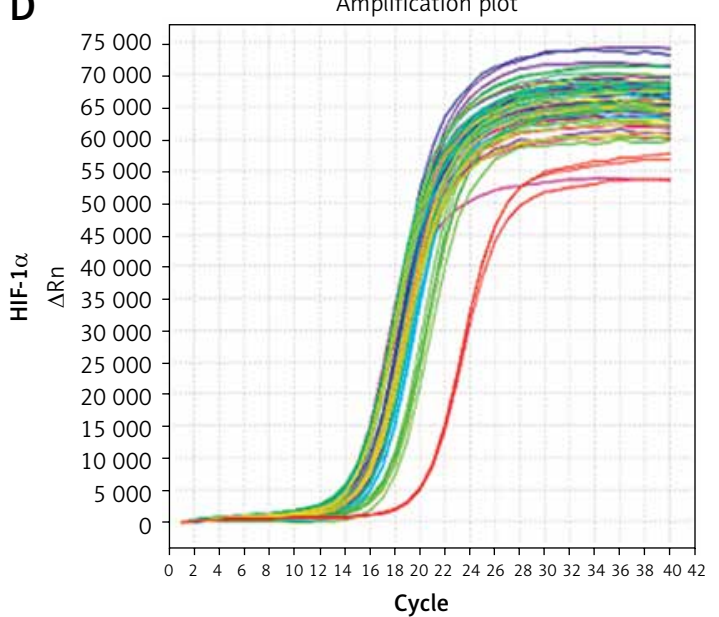

E

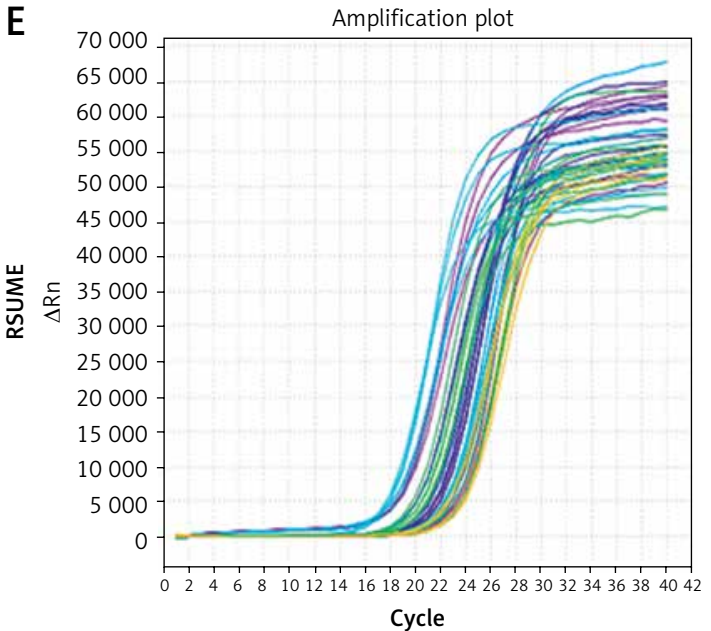

$\mathbf{F}$

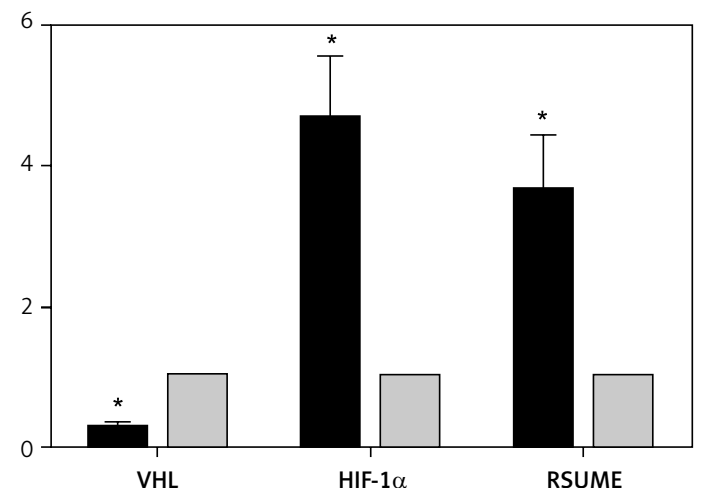

Renal cell carcinoma $(n=10) \quad \square$ Normal renal tissue $(n=10)$

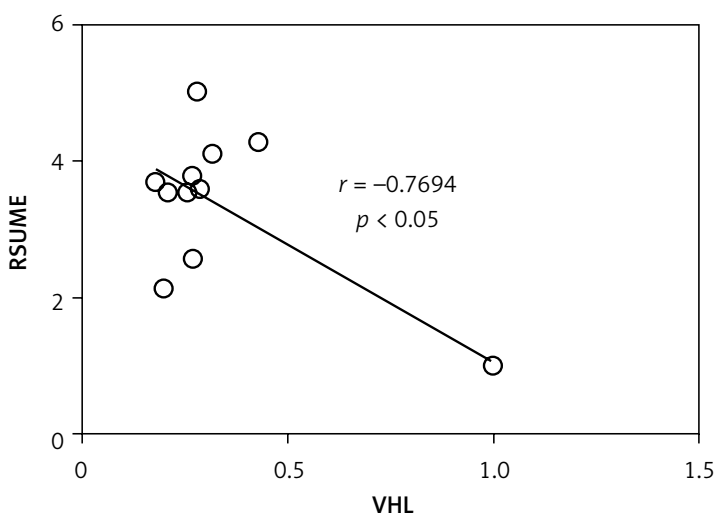

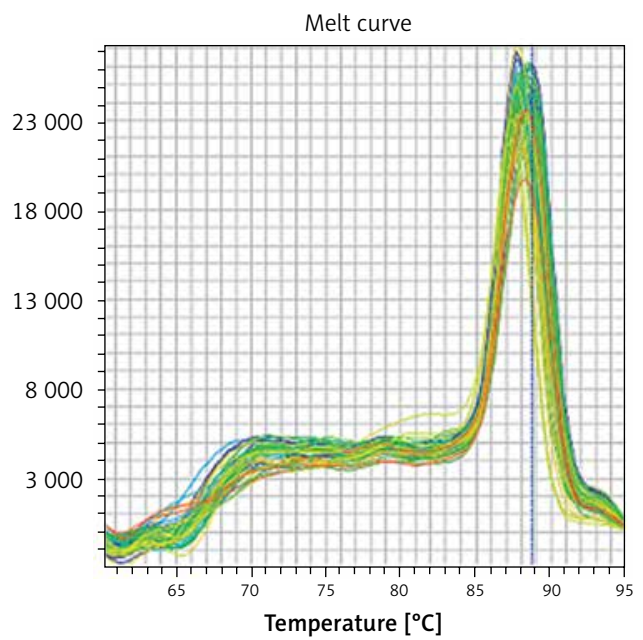

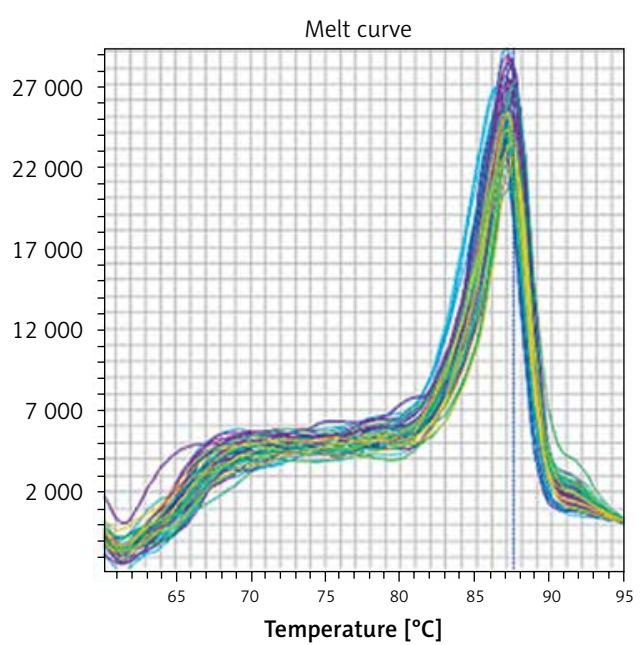

G
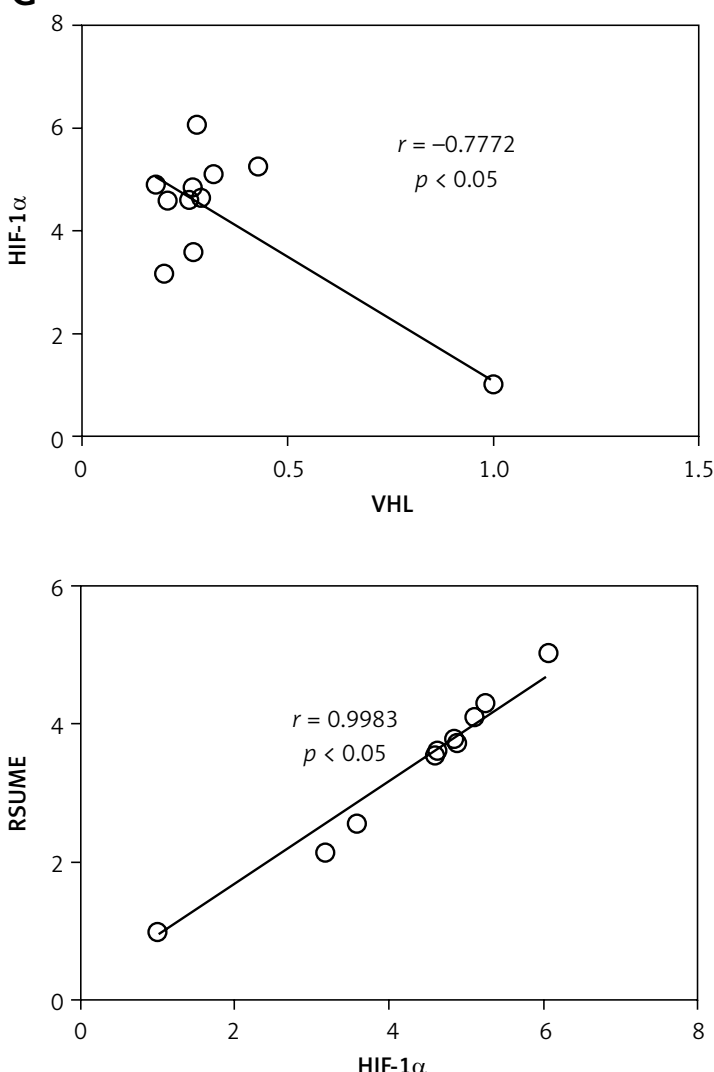

Figure 3. Cont. D - HIF-1 $\alpha$ amplification curve and dissolution curve. E - RSUME amplification curve and dissolution curve. F - Relative expression levels of VHL, HIF-1 $\alpha$, and RSUME mRNAs. G - Correlation of VHL, HIF-1 $\alpha$, and RSUME mRNAs 


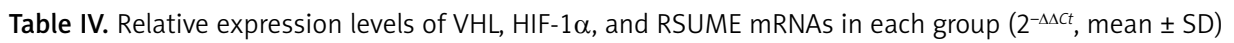

\begin{tabular}{|lccc|}
\hline Group & VHL & HIF-1 $\alpha$ & RSUME \\
\hline Normal renal tissue $(n=10)$ & 1 & 1 & 1 \\
\hline Renal cell carcinoma $(n=10)$ & $0.36 \pm 0.08^{*}$ & $1.75 \pm 0.19^{*}$ & $1.37 \pm 0.14^{*}$ \\
\hline
\end{tabular}

${ }^{*} P<0.05$ compared with normal kidney tissue.

Table V. The correlation between expression of VHL, HIF-1 $\alpha$, and RSUME and clinical parameters

\begin{tabular}{|c|c|c|c|c|}
\hline Characteristics & Number of cases & $\begin{array}{l}\text { VHL (high), HIF-1 } \alpha \\
\text { and RSUME (low) }\end{array}$ & $\begin{array}{l}\text { VHL (low), HIF-1 } \alpha \\
\text { and RSUME (high) }\end{array}$ & $P$-value ${ }^{a}$ \\
\hline Total & 20 & 10 & 10 & \\
\hline Age [years] ${ }^{\mathrm{b}}$ : & & & & 0.606 \\
\hline$<46.25$ & 15 & 7 & 8 & \\
\hline$\geq 46.25$ & 5 & 3 & 2 & \\
\hline Gender: & & & & 0.329 \\
\hline Male & 14 & 6 & 8 & \\
\hline Female & 6 & 4 & 2 & \\
\hline Tumour diameter: & & & & 0.092 \\
\hline$\leq 4 \mathrm{~cm}$ & 8 & 5 & 3 & \\
\hline$>4 \mathrm{~cm}$ & 9 & 2 & 7 & \\
\hline
\end{tabular}

There was no significant correlation between VHL, HIF-1, and RSUME expression and age, gender, and tumour diameter. ${ }^{a} \chi^{2}$ test. ${ }^{b}$ Mean age.

kidney, heart, liver, and pituitary gland [7]. Previous studies found that RSUME-encoded RWD domain protein can combine with the SUMO substrate HIF- $1 \alpha$ to form a dimer, it further promotes the SUMOylation of the substrate, it blocks the ubiquitination-proteasome degradation pathway of the protein, and it inhibits the HIF-1 $\alpha$ degradation [2, 18-20]. Shan et al. [8] confirmed in pituitary tumour cells that down-regulation of RSUME expression in hypoxia can significantly inhibit the production of HIF- $1 \alpha$, demonstrating that the production of HIF- $1 \alpha$ requires the regulation of RSUME. This was also shown in von-Hippel Lindeau disease tissue (to which RCC also belongs) [21].

However, the exact role of RSUME in RCC and its relationship with VHL/HIF signalling pathway remains unclear. Thus, this was examined in the present study.

Our results showed that the expression level of VHL mRNA and protein in RCC tissues was significantly lower compared with normal renal tissues, while the expression levels of HIF- $1 \alpha$ and RSUME mRNA and protein in RCC tissues were significantly higher compared with normal renal tissues. In addition, the expression of VHL was negatively correlated with HIF-1 $\alpha$ and RSUME, respectively. However, a positive correlation between RSUME and HIF$1 \alpha$ protein expression was observed. Our results demonstrated that inactivation of the VHL gene and accumulation of HIF-1 $\alpha$ are the key molecular bas- es of renal cell carcinoma formation, and that the upregulated expression of RSUME may contribute to the formation and development of RCC via mediation of the activity of VHL/HIF signalling pathway.

However, some limitations exist in our study. On the one hand, the sample size was very small, but to the best of our knowledge the present study is the first to demonstrate that RSUME is significantly upregulated in renal cell carcinoma tissues of patients. On the other hand, due to the lack of cell and animal experiments, our results only verify the indirect relationship between RSUME and VHL/HIF- $1 \alpha$ in renal cell carcinoma. Thus, further large-sample experiments in vivo and in vitro should be conducted to validate our observations, elucidate the molecular mechanism between RSUME, VHL, and HIF- $1 \alpha$, and predict the prognostic value of RSUME. In addition, the clinical significance of RSUME expression and the regulatory mechanism of RSUME in renal cell carcinoma also require further elucidation.

In conclusion, the relationship between $V H L$, $H I F-1 \alpha$, and RSUME genes has been preliminarily determined in renal cancer tissues. Since mutation or inactivation of the $V H L$ gene is an important molecular basis of renal cancer and its mechanism is related to up-regulation of HIF- $1 \alpha$, it is important to understand the mechanisms that promote this. We speculated that RSUME may stabilise and up-regulate the expression of HIF-1 $\alpha$ in renal cell 
carcinoma by sumoylation, which plays an important role in tumorigenesis. Further studies of the RSUME gene are expected to provide new therapeutic ideas and targets for the treatment of renal cancer.

\section{Acknowledgments}

Yuanliang Wang and Guobiao Liang contributed equally to this work.

The present study was supported by the Science and Technology Fund Project of Guizhou Province (grant no. (2015) 31).

\section{Conflict of interest}

The authors declare no conflict of interest.

\section{References}

1. Kondo K, Yao M, Yoshida M, et al. Comprehensive mutational analysis of the VHL gene in sporadic renal cell carcinoma: relationship to clinicopathological parameters. Genes Chromosomes Cancer 2002; 34: 58-68.

2. Vortmeyer AO, Choo D, Pack S, Oldfield E, Zhuang Z. VHL gene inactivation in an endolymphatic sac tumor associated with von Hippel-Lindau disease. Neurology 2000; 55: 460.

3. Baldewijns MM, van Vlodrop IJ, Vermeulen PB, Soetekouw PM, van Engeland M, de Bruine AP. VHL and HIF signalling in renal cell carcinogenesis. J Pathol 2010; 221: 125-38

4. Pavlović I, Pejić S, Radojević-Škodrić S, et al. The effect of antioxidant status on overall survival in renal cell carcinoma. Arch Med Sci 2020; 16: 94-101.

5. van der Veldt AA, Haanen JB, van den Eertwegh AJ, Boven E. Targeted therapy for renal cell cancer: current perspectives. Discov Med 2010; 10: 394-405.

6. Banyra O, Tarchynets M, Shulyak A. Renal cell carcinoma: how to hit the targets? Cent European J Urol 2013; 66: 394-404

7. Carbia-Nagashima A, Gerez J, Perez-Castro C, et al. RSUME, a small RWD-containing protein, enhances SUMO conjugation and stabilizes HIF-1alpha during hypoxia. Cell 2007; 131: 309-23.

8. Shan B, Gerez J, Haedo M, et al. RSUME is implicated in HIF-1-induced VEGF-A production in pituitary tumour cells. Endocr Relat Cancer 2011; 19: 13-27.

9. Chen X, Kuang W, Huang H, et al. Knockdown of RWD domain containing 3 inhibits the malignant phenotypes of glioblastoma cells via inhibition of phosphoinositide 3-kinase/protein kinase B signaling. Exp Ther Med 2018; 16: 384-93.

10. Livak KJ, Schmittgen TDJ. Analysis of relative gene expression data using real-time quantitative PCR and the 2- $\Delta \Delta C T$ method. Methods 2001; 25: 402-8.

11. Sato Y, Yoshizato T, Shiraishi Y, et al. Integrated molecular analysis of clear-cell renal cell carcinoma. Nat Genet 2013; 45: 860-7.

12. The Cancer Genome Atlas Research Network. Comprehensive molecular characterization of clear cell renal cell carcinoma. Nature 2013; 499: 43.

13. Hughson MD, He Z, Liu S, Coleman J, Shingleton WB. Expression of HIF-1 and ubiquitin in conventional renal cell carcinoma: relationship to mutations of the von
Hippel-Lindau tumor suppressor gene. Cancer Genetics Cytogenet 2003; 143: 145-53.

14. Maxwell PH, Pugh CW, Ratcliffe PJ. The pVHL-hIF-1 system. A key mediator of oxygen homeostasis. Adv Exp Med Biol 2001; 502: 365-76.

15. Fuertes M, Gerez J, Haedo M, et al. Cytokines and genes in pituitary tumorigenesis: RSUME role in cell biology. Front Hormone Res 2010; 38: 1-6.

16. Melchior F. SUMO: nonclassical ubiquitin. Ann Rev Cell Developm Biol 2000; 16: 591-626.

17. Vertegaal AC, Ogg SC, Jaffray E, et al. A proteomic study of SUMO-2 target proteins. J Biol Chem 2004; 279: 33791-8.

18. Fowkes RC, Vlotides G. Hypoxia-induced VEGF production 'RSUMEs' in pituitary adenomas. Endocrine Relat Cancer 2012; 19: C1-5.

19. Gerez J, Fuertes M, Tedesco L, et al. In silico structural and functional characterization of the RSUME splice variants. PLoS One 2013; 8: e57795.

20. Chan JY, Tsai CY, Wu CH, et al. Sumoylation of hypoxia-inducible factor-1alpha ameliorates failure of brain stem cardiovascular regulation in experimental brain death. PLoS One 2011; 6: e17375.

21. Bonora M, Wieckowski MR, Chinopoulos C, et al. Molecular mechanisms of cell death: central implication of ATP synthase in mitochondrial permeability transition. Oncogene 2015; 34: 1475. 